\title{
Climate versus carbon dioxide controls on biomass burning: a model analysis of the glacial-interglacial contrast
}

\author{
M. Martin Calvo ${ }^{1}$, I. C. Prentice ${ }^{2,3}$, and S. P. Harrison ${ }^{3,4}$ \\ ${ }^{1}$ Department of Life Sciences, Imperial College London, Silwood Park Campus, Buckhurst Road, Ascot SL5 7PY, UK \\ ${ }^{2}$ AXA Chair of Biosphere and Climate Impacts, Grand Challenges in Ecosystems and the Environment and Grantham \\ Institute - Climate Change and Environment, Department of Life Sciences, Imperial College London, Silwood Park Campus, \\ Buckhurst Road, Ascot SL5 7PY, UK \\ ${ }^{3}$ Department of Biological Sciences, Macquarie University, North Ryde, NSW 2109, Australia \\ ${ }^{4}$ Centre for Past Climate Change and School of Archaeology, Geography and Environmental Sciences (SAGES), \\ University of Reading, Whiteknights, RG6 6AH, Reading, UK
}

Correspondence to: M. Martin Calvo (marmarcal@gmail.com)

Received: 7 January 2014 - Published in Biogeosciences Discuss.: 12 February 2014

Revised: 16 September 2014 - Accepted: 21 September 2014 - Published: 5 November 2014

\begin{abstract}
Climate controls fire regimes through its influence on the amount and types of fuel present and their dryness. $\mathrm{CO}_{2}$ concentration constrains primary production by limiting photosynthetic activity in plants. However, although fuel accumulation depends on biomass production, and hence on $\mathrm{CO}_{2}$ concentration, the quantitative relationship between atmospheric $\mathrm{CO}_{2}$ concentration and biomass burning is not well understood. Here a fire-enabled dynamic global vegetation model (the Land surface Processes and eXchanges model, LPX) is used to attribute glacial-interglacial changes in biomass burning to an increase in $\mathrm{CO}_{2}$, which would be expected to increase primary production and therefore fuel loads even in the absence of climate change, vs. climate change effects. Four general circulation models provided last glacial maximum (LGM) climate anomalies that is, differences from the pre-industrial (PI) control climate - from the Palaeoclimate Modelling Intercomparison Project Phase 2, allowing the construction of four scenarios for LGM climate. Modelled carbon fluxes from biomass burning were corrected for the model's observed prediction biases in contemporary regional average values for biomes. With LGM climate and low $\mathrm{CO}_{2}(185 \mathrm{ppm})$ effects included, the modelled global flux at the LGM was in the range of 1.0-1.4 $\mathrm{PgC}_{\text {Cear }}{ }^{-1}$, about a third less than that modelled for PI time. LGM climate with pre-industrial $\mathrm{CO}_{2}$ (280 ppm) yielded unrealistic results, with global biomass burning fluxes similar to or even greater than in the pre-
\end{abstract}

industrial climate. It is inferred that a substantial part of the increase in biomass burning after the LGM must be attributed to the effect of increasing $\mathrm{CO}_{2}$ concentration on primary production and fuel load. Today, by analogy, both rising $\mathrm{CO}_{2}$ and global warming must be considered as risk factors for increasing biomass burning. Both effects need to be included in models to project future fire risks.

\section{Introduction}

Biomass burning, which is a major factor influencing terrestrial carbon fluxes to the atmosphere (Andreae and Merlet, 2001; Prentice et al., 2011a; Seiler and Crutzen, 1980), is strongly determined by fuel availability and dryness (Aldersley et al., 2011; Bistinas et al., 2013; Krawchuk et al., 2009; Krawchuk and Moritz, 2009, 2011; Moritz et al., 2013; Bistinas et al., 2014). Both are influenced by climate: shortterm stochastic climate variability (weather) controls ignitions through lightning and fuel moisture and fire spread through temperature, precipitation, moisture and wind speed; long-term climate controls vegetation type and productivity, and hence fuel production (Bowman et al., 2009; Dale et al., 2000; Flannigan et al., 2000; Harrison et al., 2010). However, vegetation type and productivity are also directly influenced by atmospheric $\mathrm{CO}_{2}$ concentration (Cowling, 1999; Farquhar, 1997; Prentice and Harrison, 2009), allowing the 
possibility that anthropogenic changes in atmospheric $\mathrm{CO}_{2}$ concentration could influence biomass burning via changes in the types and quantities of fuel (Harrison et al., 2010; Koch and Mooney, 1996; Moritz et al., 2005). Very little information is currently available about these potential effects.

Progress in differentiating between the large-scale controls of fire by $\mathrm{CO}_{2}$ and climate could in principle be made by evaluating changes in fire regimes with the help of global vegetation-fire models which (a) are based on a solid foundation of knowledge at the process level, including the physiology of photosynthesis and the physiological effects of $\mathrm{CO}_{2}$ on plants with different photosynthetic pathways, and (b) have been shown to reproduce major spatial and temporal patterns in fire regimes as observed from space. Nevertheless, the available global data on changes in biomass burning do not span a sufficiently wide array of environmental conditions to allow modelled $\mathrm{CO}_{2}$ effects to be tested directly. This is because the most reliable remotely sensed record of burnt area is that obtained from the MODIS instrument, which was launched as recently as 2000 CE (Giglio et al., 2010). Any effects of the increase in $\mathrm{CO}_{2}$ concentration on biomass burning over this interval are likely to have been overwhelmed by the effects of spatial and interannual variability in climate.

As an alternative approach, here we use process-based modelling together with palaeodata which document the response of fire regimes to environmental changes on a longer timescale, encompassing the large natural variations in atmospheric $\mathrm{CO}_{2}$ concentration between glacial and interglacial climates. Sedimentary charcoal records provide information about changes in fire regimes with sometimes annual, but more generally multi-decadal, resolution over such long periods. When appropriately processed (Power et al., 2010), these records can be combined to provide composite regional and global histories (see e.g. Power et al., 2008; Marlon et al., 2009; Daniau et al., 2010, 2012; Mooney et al., 2011) of changes in fire regimes on multi-millennial timescales. Power et al. (2008) analysed charcoal records covering the last 21000 years. Although regional patterns in fire regimes were shown to differ between the last glacial maximum (LGM, ca. 21000 years ago, $21 \mathrm{kaBP}$ ) and the recent past, fire prevalence in most regions was low at the LGM and until about 16000 years BP, after which there was a gradual transition to the higher fire prevalence characteristic of the Holocene. Daniau et al. (2012) confirmed this global pattern with an analysis of a more extensive data set, and suggested that it could be largely explained in terms of changing temperature and moisture controls. Specifically, Daniau et al. (2012) showed that fire increased monotonically with temperature, and peaked at intermediate moisture levels. Changes in fire regime, both on regional and global scales, tracked the glacial-interglacial increase in temperature. The strong correlation between biomass burning (indexed by charcoal abundance) and local temperature and moisture regimes was assumed to reflect climate controls on productivity, fuel accumulation and fuel dryness.
However, the glacial-interglacial transition was also characterized by a progressive, nearly $100 \mathrm{ppm}$ increase in $\mathrm{CO}_{2}$ concentration. Large-scale effects of temperature increase (driven in part by rising $\mathrm{CO}_{2}$ ) and ecophysiological effects of rising $\mathrm{CO}_{2}$ on vegetation and primary production cannot be readily distinguished based on time-series information alone (Prentice and Harrison, 2009; Bennett et al., 2013), because of their temporal correlation. However, process-based modelling can make the distinction. Harrison and Prentice (2003) showed using the BIOME4 model that ecophysiological $\mathrm{CO}_{2}$ effects are required to account for the full extent of the reduction in global forest cover during glacial times. The same general approach and model was used by Bragg et al. (2013) to demonstrate that observed glacial-interglacial changes in the stable carbon isotope signature of vegetation in southern Africa are dominated by ecophysiological $\mathrm{CO}_{2}$ effects. Prentice et al. (2011b) demonstrated that the LPX model produced realistic patterns of biome distribution at the LGM when driven by climate outputs from four coupled ocean-atmosphere general circulation models from the Palaeoclimate Modelling Intercomparison Project Phase 2 (PMIP2) and with the observed LGM atmospheric $\mathrm{CO}_{2}$ level; but they did not analyse the modelled fire regimes, nor did they explicitly separate climate and $\mathrm{CO}_{2}$ effects on vegetation.

Here we apply the LGM climate scenarios used by Prentice et al. (2011a) to drive the LPX model (Prentice et al., 2011b). Our aim was to demonstrate whether a qualitatively realistic simulation of the patterns of biomass burning at the LGM vs. pre-industrial time could be obtained by modelling; and, if so, to assess the extent to which the well-documented increase in global biomass burning from the LGM to the Holocene could be explained by climate change alone, vs. the alternative of climate change together with the ecophysiological effects of increased $\mathrm{CO}_{2}$.

\section{Methods}

LPX (Prentice et al., 2011b) was developed from the Lund-Potsdam-Jena SPread and InTensity of FIRE (LPJSPITFIRE) model (Thonicke et al., 2010), which in turn was a development of the original LPJ (Sitch et al., 2003; Gerten et al., 2004) dynamic global vegetation model. LPJ simulates vegetation dynamics, and land-atmosphere exchanges of water and $\mathrm{CO}_{2}$, using a set of nine plant functional types (PFT): tropical broadleaved evergreen tree, tropical broadleaved raingreen tree, temperate needleleaved evergreen tree, temperate broadleaved evergreen tree, temperate broadleaved summergreen tree, boreal needleleaved evergreen tree, boreal broadleaved summergreen tree, $\mathrm{C}_{3}$ perennial grass/forb and $\mathrm{C}_{4}$ perennial grass/forb. Each PFT has different dynamics in terms of production and physiological responses to climate. Photosynthetic activity (gross primary production) depends on water availability, temperature, atmospheric 
$\mathrm{CO}_{2}$ concentration and photosynthetically active radiation (a function of insolation and cloudiness). Net primary production accounts for carbon loss through respiration by plant tissues (Sitch et al., 2003) and is assumed to equate with biomass growth.

LPJ-SPITFIRE and LPX were designed to improve on the simple representation of fire in LPJ by explicitly modelling the rate at which fire spreads as a function of wind speed and physical properties (including dryness) of the fuel, and responses of the vegetation itself (including different mortality mechanisms) to the intensity and combustion efficiency of fires. Litter drying is calculated using a simplified form of the Nesterov Index. The daily accumulation of this index depends on atmospheric dryness (the diurnal temperature range is used as an approximation for this purpose) and maximum temperature. Accumulation takes place over precipitationfree periods, which are modelled stochastically as a function of monthly wet-day frequency (Gerten et al., 2004). The rate of fire spread then follows the Rothermel equations (Rothermel, 1972). Thonicke et al. (2010) described the full set of equations and parameters in the fire component of LPJSPITFIRE, and Prentice et al. (2011b) documented the modifications made in LPX. Although LPJ-SPITFIRE accounts for both natural and human ignitions, lightning is the only ignition source in LPX. Only allowing natural ignitions is appropriate for palaeo-simulations when potential human ignitions are not of key importance on a global scale. LPX produces reasonable simulations of fire regimes under modern conditions, including the spatial and seasonal patterns of burnt area (Prentice et al., 2011b). Kelley et al. (2013) performed quantitative comparisons of model outputs against a set of benchmarks, showing that both LPJ and LPX can produce reasonably good simulations of vegetation, carbon- and water-cycle characteristics including vegetation cover (as the fraction of absorbed photosynthetically active radiation, fAPAR), gross primary production (GPP), net primary production (NPP), canopy height, net ecosystem carbon exchange and runoff. However, LPX produces a much better simulation of the spatial and temporal patterns of burnt area than LPJ.

We used outputs from four coupled ocean-atmosphere models (HadCM3M2, MIROC3.2, FGOALS-1.0g and CNRM-CM33) to derive LGM climate variables for the LPX model. The LGM simulations were carried out following the PMIP2 protocol (Braconnot et al., 2007), with orbital parameters for $21 \mathrm{kaBP}$, expanded ice sheets and changes in land-sea geography specified by Peltier (2004), and greenhouse gas concentrations derived from ice-core records $\left(\mathrm{CO}_{2}: 185 \mathrm{ppm}, \mathrm{CH}_{4}: 350 \mathrm{ppb}, \mathrm{N}_{2} \mathrm{O}: 200 \mathrm{ppb}\right)$. The control is a pre-industrial (PI: 1750 CE) simulation, with greenhouse gas concentrations corresponding to $1750 \mathrm{CE}$ $\left(\mathrm{CO}_{2}: 280 \mathrm{ppm}, \mathrm{CH}_{4}: 760 \mathrm{ppb}, \mathrm{N}_{2} \mathrm{O}: 270 \mathrm{ppb}\right)$ and orbital parameters set to $1950 \mathrm{CE}$ values (the difference in insolation patterns between 1750 and $1950 \mathrm{CE}$ is negligible). Anomalies (i.e. the difference between LGM and PI gridded val- ues) of monthly temperature, precipitation and cloudiness were bilinearly interpolated to the $0.5^{\circ}$ grid used by LPX and then added to detrended values of these variables for the period 1900-1950 from the TS 3.0 version of the Climate Research Unit (CRU) data set. A widely used weather generation approach is used to convert monthly precipitation and wet-day inputs into a time course of daily precipitation values, as required for predictions of hydrological regimes and (especially) for fire probabilities, which depend strongly on fuel moisture and therefore on the length of the periods between precipitation events. The outcome of these procedures is a high-resolution LGM climate scenario, preserving interannual variability, for each climate model used as input. Although several other modelling groups ran LGM simulations in PMIP2, the four selected models are representative of the range of simulated LGM climates (Harrison et al., 2014). Furthermore, Prentice et al. (2011a) have already shown that they produce a reasonably good simulation of global vegetation patterns, as shown by pollen-based reconstructions for the LGM.

The simulated outputs used for the purposes of this study were: carbon flux from fire (which accounts for biomass burning), burnt area, NPP, "fast" and "slow" carbon pools, annual mean growing degree days above a baseline temperature of $5^{\circ} \mathrm{C}$ (GDD), foliage projective cover (FPC), dominant plant functional type (PFT) and canopy height. In order to display the overall impact of changes in $\mathrm{CO}_{2}$ and climate on vegetation distribution, we used an algorithm that converts modelled vegetation properties into 12 broad vegetation types (or biomes) based on simulated canopy height, FPC, PFT and GDD (Prentice et al., 2011b). A climatic criterion (low GDD) is used to discriminate arctic-alpine biomes from the rest. This is because LPX, in common with many other vegetation models, does not explicitly characterize tundra plants as a distinct PFT. A low GDD criterion has often been used in static biogeography models to characterize tundra (see e.g. Sykes et al., 1996). We used ensemble averages of these variables for the four LGM simulations with LGM $\mathrm{CO}_{2}$ and the four LGM simulations with pre-industrial $\mathrm{CO}_{2}$ to derive biome maps. The pre-industrial biome distribution was simulated using the detrended CRU climate data and preindustrial $\mathrm{CO}_{2}$.

Charcoal data are used to provide regional indices of biomass burning. Due to the transformation necessarily involved in the processing of sedimentary charcoal records, the data cannot be interpreted in a strictly quantitative way. However, relative changes in the charcoal index for a region give unambiguous information about the sign of change and an indication of the relative magnitude of changes between different intervals. Comparisons are made here between relative changes in biomass burning between LGM and PI, as modelled (with LGM $\mathrm{CO}_{2}$ or PI $\mathrm{CO}_{2}$ ), and as represented in the charcoal data assembled by Daniau et al. (2012) for the LGM and recent times. The charcoal-derived values are averages for the period 22-20 ka BP to represent the LGM, 
and from 850 to $1750 \mathrm{CE}$ for PI. The interval $22-20 \mathrm{kaBP}$ is conventionally used to represent the LGM in syntheses of data (see e.g. Bartlein et al., 2011) and the PI interval was chosen to avoid major human influence on fire regimes (see e.g. Marlon et al., 2008). The charcoal-derived averages were compared to a 30-year average of the simulated biomass burning. Relative changes were calculated as

$R=\frac{X-X_{\text {ref }}}{X_{\text {ref }}}$

where $X$ is the LGM value and $X_{\text {ref }}$ is the corresponding PI value for each latitudinal band. The latitudinal bands considered are southern extratropical (SET, $>30^{\circ} \mathrm{S}$ ), southern tropical $\left(\mathrm{ST}, 0-30^{\circ} \mathrm{S}\right)$, northern tropical $\left(\mathrm{NT}, 0-30^{\circ} \mathrm{N}\right)$ and northern extratropical (NET, $\left.>30^{\circ} \mathrm{N}\right)$. Although the amount of charcoal production shows large variations between biomes, this approach compares fire occurrence in relative terms, and as the emission factors for each biome are based on published data we assume that carbon flux from fire is systematically related to the amount of charcoal produced.

There are known biases. LPX tends consistently to underestimate burnt area in forested regions and overestimate burnt area in non-forested regions (Kelley et al., 2013). The bias in non-forested regions is probably due to an overestimation of NPP on areas limited by fuel, which leads to bigger areas being burned and more carbon being released to the atmosphere. Areas with higher precipitation rates, on the other hand, have simulated drying rates which are too low, preventing the simulation of open woody vegetation that would be more susceptible to burning. This problem explains in particular the large underestimation of fire in boreal forests. Kelley et al. (2014) have recently addressed these issues in an improved version of LPX applied to Australia, but this version has not yet been tested globally.

The standard version of LPX used here simulates the main features and spatial patterns of modern fire regimes well, albeit with quantitative biases that are expected to be corrected in future modelling work. However the LGM to PI transition involves large changes in the relative global coverage of forests vs. other vegetation types (Prentice et al., 2011a), and thus it was important for this study to minimize the effect of these biases on global fire statistics. This was done by classifying modelled vegetation into biomes (as described above) and then calculating the ratio of multi-annual mean burnt area within each biome from GFED3 to the multi-annual mean burnt area simulated by LPX under the present climate (Table 1). We applied these ratios as correction factors to the "raw" simulated burnt area in both the PI and LGM climates. We excluded agricultural, peat and deforestation fires from the GFED data in order to derive estimates closer to the simulations (which do not include these categories of fires). The separation of different types of fire in GFED is specified according to emissions rather than burnt area, so the corrections were applied directly to emissions. The ratios were cal-
Table 1. Correction factors (rounded to two decimal places) for biomass burning, based on the ratio between GFED3 (nonanthropogenic) biomass burning and simulated biomass burning for each biome (uncertainties in parentheses).

\begin{tabular}{lc}
\hline Biome & $\begin{array}{c}\text { Biomass burning ratio } \\
\text { (GFED/simulations) }\end{array}$ \\
\hline Tropical forest & $2.96(0.51)$ \\
Temperate forest & $0.05(0.01)$ \\
Boreal forest & $379.96(116.06)$ \\
Tropical savannah & $0.95(0.11)$ \\
Temperate parkland & $0.04(0.01)$ \\
Dry grass/shrub & $0.18(0.15)$ \\
Desert & $0.03(0.01)$ \\
Shrub tundra & $0.28(0.02)$ \\
Tundra & $0.19(0.07)$ \\
\hline
\end{tabular}

culated using the following selected regions for each of the biomes:

- Tropical forest: S America, Asia, Africa

- Temperate forest: $\mathrm{N}$ America, Eurasia

- Boreal forest: N America, Eurasia

- Tropical savannah: N Australia, N Africa, S Africa

- Temperate parkland: N America, Eurasia

- Dry grass/shrubland: Aral sea region, Australia, Great Basin USA

- Desert: Sahara Desert, Middle East, Gobi Desert

- Shrub tundra: N America, Eurasia

- Tundra: N America, Eurasia

Our broad definition of tropical forests includes tropical dry forests, which are a significant natural source of global $\mathrm{CO}_{2}$ emissions (Batchelder, 1967; Stott et al., 1990; Middleton et al., 1997; Stott, 2000; Keeley and Bond, 2001; Roberts, 2001). Even if most of the burnt area in tropical moist forests today is linked to deforestation, tropical dry forests are floristically and structurally intermediate between tropical moist forests and savannahs, and are prone to lightning-set fires. Warm temperate forest, sclerophyll woodland and boreal parkland were not considered for correction because their distribution area is much more restricted, and less accurately simulated, than other biomes. Ratios were calculated by dividing the total amount of carbon released from the selected areas in the GFED data by the same quantity in the present vegetation simulations, based on CRU TS3.0 climate for the period 1997-2011. Uncertainties of the ratios were attributed 
using the formula:

$$
\begin{aligned}
U(b) & =\frac{\operatorname{AvgGFED}(b)+\frac{\operatorname{MaxGFED}(b)-\operatorname{MinGFED}(b)}{2}}{\operatorname{AvgPI}(b)+\frac{\operatorname{MaxPI}(b)-\operatorname{MinPI}(b)}{2}} \\
& -\frac{\operatorname{SumGFED}(b)}{\operatorname{SumPI}(b)}
\end{aligned}
$$

where $U(b)$ is the calculated uncertainty for biome $b$, and Avg, Max, Min and Sum represent the average, maximum, minimum and summed values from the PI simulation and GFED, respectively. These ratios were multiplied by the total simulated biomass burning rates per biome for all simulations. We also calculated area burned as a fraction of total area, and carbon released through burning as a fraction of total carbon uptake, for each biome.

As a further check on the realism of the simulation of the changing terrestrial carbon cycle, simulated global carbon pools (soil and vegetation) were compared with independently estimated global values, based on $\delta^{13} \mathrm{C}$ changes from ocean sedimentary records and ice core records, for the PI (Denman et al., 2007) and LGM (Ciais et al., 2011). These estimates include an inert pool associated with permafrost. Since LPX does not simulate permafrost, our comparisons are confined to the active pool estimated by Denman et al. (2007) and Ciais et al. (2011).

\section{Results}

Simulated carbon pools (Fig. 1) are in good agreement with results presented by Ciais et al. (2011). According to the simulations, LGM carbon storage was reduced by $40-52 \%$ (depending on the climate model used for the simulations), similar to the $43 \%$ reduction inferred by Ciais et al. (2011). The model results indicate that the reduction was mainly due to the ecophysiological effect of changes in $\mathrm{CO}_{2}$ concentration, as carbon accumulation was similar to or even greater than pre-industrial in the LGM simulations when $\mathrm{CO}_{2}$ was kept unchanged at PI levels. This finding supports the suggestion of Prentice and Harrison (2009) and Prentice et al. (2011a) that the increase in carbon storage from LGM to Holocene was primarily caused by $\mathrm{CO}_{2}$. Between 27 and $30 \%$ of the global land area was covered by forest in the LGM simulations with PI $\mathrm{CO}_{2}$ whereas under $\mathrm{LGM} \mathrm{CO}_{2}$ only $15-16 \%$ of the global land area was covered by forest (Fig. 2). The area of tropical forests, in particular, was 21-31\% under LGM climate and PI $\mathrm{CO}_{2}$, whereas simulations using $\mathrm{LGM} \mathrm{CO}_{2}$ showed a 60-63\% reduction of tropical forests, with higher levels of fragmentation - consistent with tropical pollen records (Harrison and Prentice, 2003), and with offshore leaf-wax $\delta^{13} \mathrm{C}$ records from tropical southern Africa (Bragg et al., 2013), both of which indicate a major reduction in the area occupied by forests at the LGM.

Figure 3 shows the simulated changes in the carbon flux from biomass burning according to biomes. Without correc-

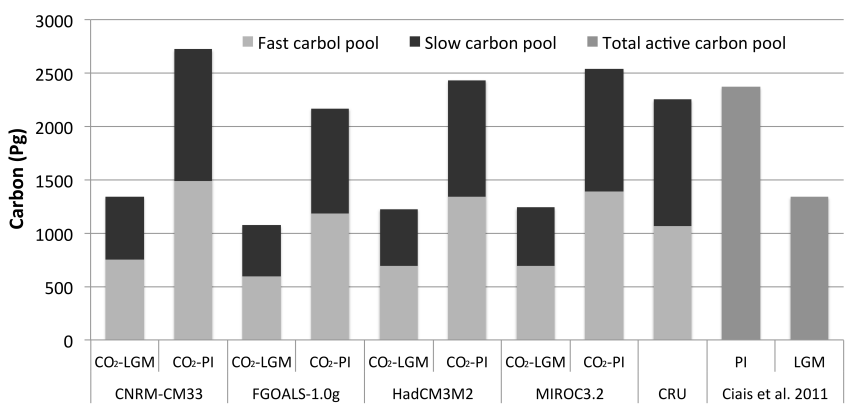

Figure 1. Amounts of carbon in the fast- and slow-decomposing carbon pools simulated by LPX when driven by climate outputs from the four LGM simulations and with either LGM or PI $\mathrm{CO}_{2}$. CRU represents the PI climate simulation under CRU TS3.0 climate. The simulated total carbon is compared to estimates of the total active pool by Ciais et al. (2011).

tion for known contemporary biases (Fig. 3, top), the modelled global biomass burning flux at the LGM (with realistic $\mathrm{CO}_{2}$ ) is apparently larger than that modelled for PI conditions. However, most of this simulated biomass burning at the LGM is due to non-forest biomes (including temperate parkland, dry grass/shrub and desert) whose emissions are overestimated by large factors (Table 1). After bias correction, modelled biomass burning flux becomes $24-43 \%$ less under LGM conditions, ranging from 1.0 to $1.4 \mathrm{PgC} \mathrm{year}^{-1}$ across the four LGM climate scenarios.

The modelled biomass burning flux at the LGM is still dominated by emissions from non-forest biomes, even after bias correction (Fig. 3). Changes in biome areas, especially the major reduction in the area occupied by forests, are simulated fairly consistently in all four scenarios and contribute strongly to the reduction in modelled biomass burning. The simulations also indicate changes in the fractional area burned as a consequence of the LGM climate (greatly decreased in forest and tundra biomes, increased in non-forest biomes), and a general increase in fractional area burned when PI $\mathrm{CO}_{2}$ is imposed (Table 2, left columns). Biomass burned per unit area of tropical forests is strongly reduced in the LGM climate, but this effect is cancelled and turned into a large increase when $\mathrm{PI} \mathrm{CO}_{2}$ is imposed (Table 2, middle columns). The fraction of annual NPP lost to the atmosphere through burning is greatly reduced in the LGM climate, both in tropical forests and in savannahs. This effect is partly counteracted, but not cancelled, by imposing PI $\mathrm{CO}_{2}$ (Table 2, right columns).

The large effect of $\mathrm{CO}_{2}$ concentration on the burnt fraction of NPP in tropical savannahs and forests (Table 2, right columns) is notable. A major modelled effect of low $\mathrm{CO}_{2}$ concentration in the Tropics is reduced tree cover, whereas the $\mathrm{C}_{4}$ grasses that dominate in tropical savannahs (and are present in fire-prone tropical dry forests) continue to thrive. Savannah and tropical forest emissions include a major contribution from the woody component, so the reduction in tree 

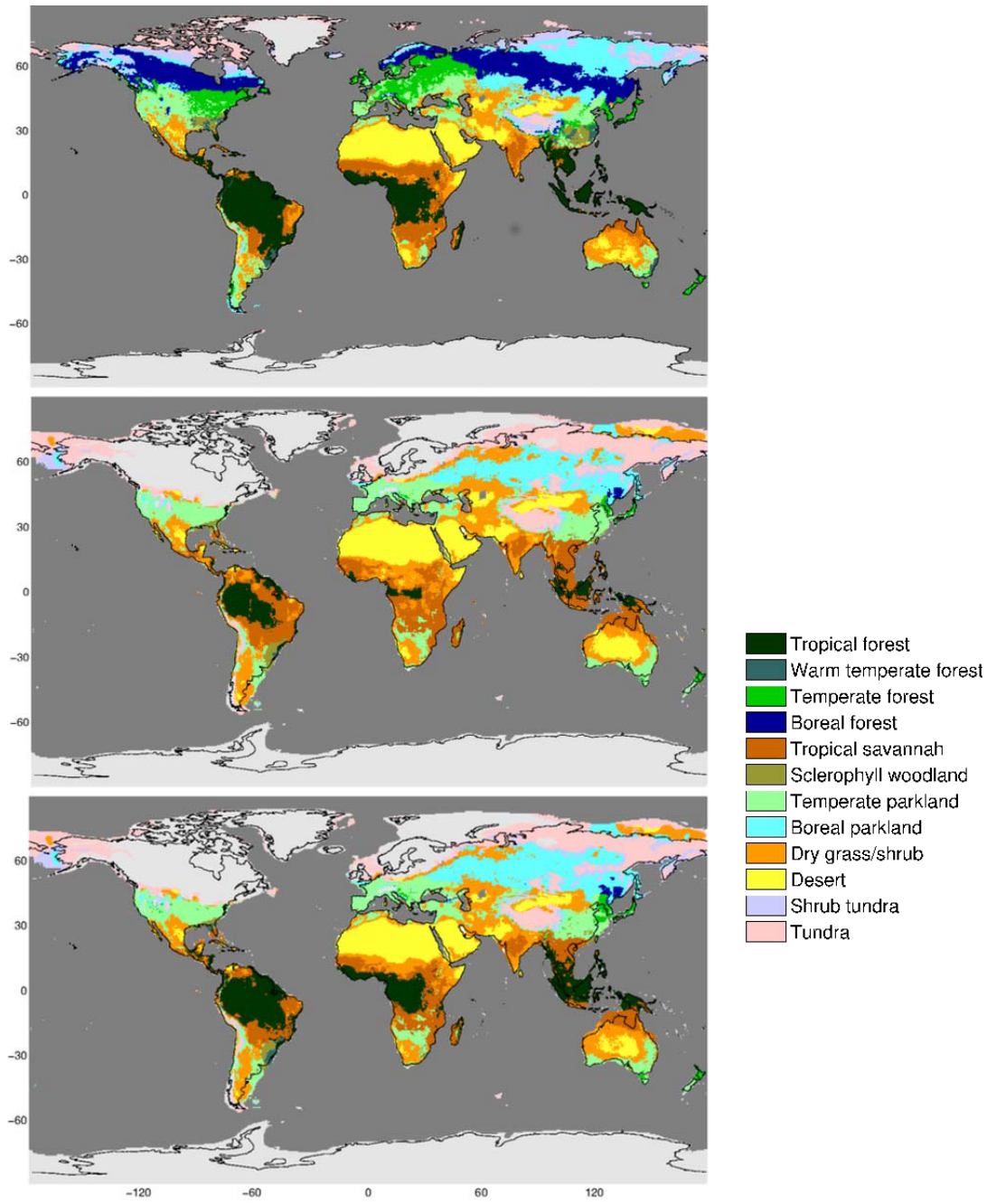

Temperate parkland

Boreal parkland

Dry grass/shrub

Desert

Shrub tundra

Tundra

Figure 2. Biome distributions derived from LPX simulations for PI climate and $\mathrm{CO}_{2}$ (top), $\mathrm{LGM}$ climate and $\mathrm{CO}_{2}$ (middle), and $\mathrm{LGM}$ climate with $\mathrm{PI} \mathrm{CO}_{2}$ (bottom). The LGM simulations were driven by average climate anomalies from the four scenarios.

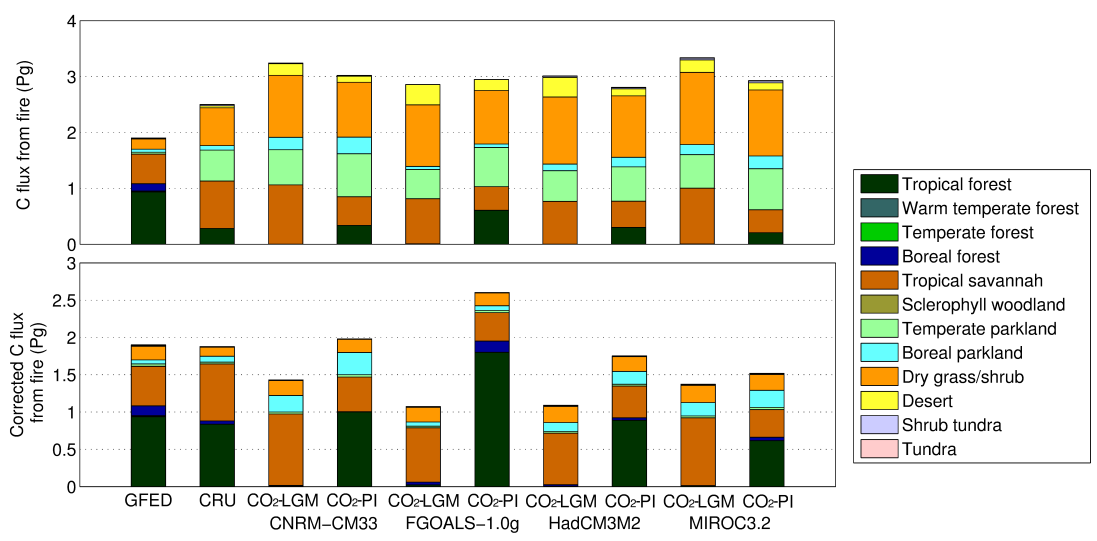

Figure 3. Simulated carbon fluxes from fire $\left(\mathrm{PgC}_{\mathrm{Cear}}{ }^{-1}\right)$ for each biome under PI climate and $\mathrm{CO}_{2}\left(\mathrm{CRU}_{\mathrm{TS} 3.0)}\right)$, LMM climate and CO 2 , and LGM climate with PI $\mathrm{CO}_{2}$ under all four LGM climate model conditions: uncorrected results (top) and results after correction for contemporary biases (bottom). 
cover translates into an important reduction in the fraction of NPP consumed.

The net global effect of $\mathrm{LGM} \mathrm{CO}_{2}$ is a strong suppression of biomass burning, according to the bias-corrected model results (Fig. 3). In the LGM climate with imposed (unrealistic) $\mathrm{PI} \mathrm{CO}_{2}$ the modelled global biomass burning flux is similar to (in fact, on average slightly greater than) that for the PI climate; the distribution among biomes is relatively similar to that in the PI climate. With LGM climate and LGM $\mathrm{CO}_{2}$, only $0.6-2 \%$ of the flux originates in tropical forests. With LGM climate and $\mathrm{PI} \mathrm{CO}_{2}$ this figure rises to $41-69 \%$, in response to the unrealistically large simulated areas of this biome under $\mathrm{PI} \mathrm{CO}_{2}$, and the higher rates of biomass burned per unit area due to the increase of productivity in tropical forests (Table 2, middle columns).

The LGM climate results in a general reduction of biomass burning in the southern tropical latitude band in particular (Fig. 4). Again $\mathrm{CO}_{2}$ has an impact here. Compared to the LGM simulations with imposed PI $\mathrm{CO}_{2}$, the LGM simulations with realistic $\mathrm{CO}_{2}$ show a reduction in biomass burning rates across all latitude bands, with the exception of the Southern Tropics in two models.

Comparisons with charcoal data (Fig. 5) indicate that the large biomass burning fluxes modelled with LGM climate and $\mathrm{PI} \mathrm{CO}$, especially the consistently and greatly increased fluxes in the Northern Hemisphere, are wholly unrealistic. By contrast, the modelled biomass burning fluxes with LGM climate and $\mathrm{LGM} \mathrm{CO}$ show a pattern more consistent with the charcoal data, with realistic reductions relative to PI in the Southern Hemisphere and globally. However, three out of the four models simulate a marginal increase in biomass burning at the LGM in the Northern Tropics and a large increase in the Northern Extra-Tropics, whereas the charcoal data unequivocally show a reduction in both latitude bands.

\section{Discussion}

Above-ground detritus (litter), which is of major importance in the initiation and spread of fires, in these four LGM scenarios was calculated to amount to an average of $142 \mathrm{PgC}$ for the PI and $79 \mathrm{PgC}$ for the LGM (Prentice et al., 2011a). Our results suggest that the ecophysiological effect of $\mathrm{CO}_{2}$ on primary production, and thus litter accumulation and biomass burning, provided the dominant contribution to the observed increase in biomass burning from the LGM to the Holocene. This effect arises because $\mathrm{CO}_{2}$ concentration - especially at the low end of its natural range, where the $\mathrm{CO}_{2}$ response of photosynthesis is steepest - is a major control on net primary production, and therefore also on the amount of fuel available and, indirectly, the amount of carbon that returns to the atmosphere through burning. The simulated effect was strong in the Tropics, where low $\mathrm{CO}_{2}$ dramatically reduced the modelled area occupied by forests, the fraction of NPP consumed by fire in tropical forests and savannahs, and the total global

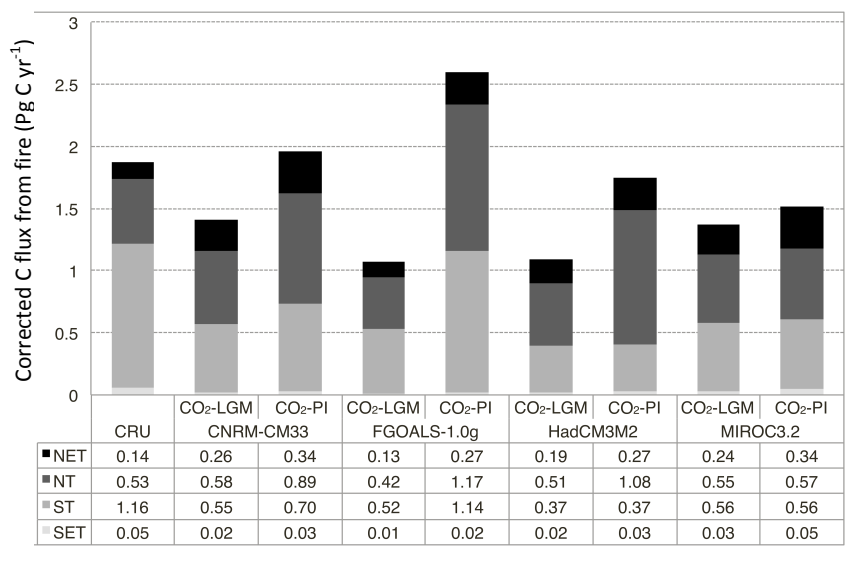

Figure 4. Simulated carbon flux from biomass burning $\left(\mathrm{PgC}_{\mathrm{C} e a r}{ }^{-1}\right)$ by latitude bands, after applying the biome correction. The CRU column represents the PI simulation using CRU TS3.0 climate; the rest of the columns represent the values for each of the modelled LGM climates and the two $\mathrm{CO}_{2}$ scenarios. The latitude bands are Northern Extra-Tropics (NET, 30-70 $\mathrm{N}$ ), Northern Tropics (NT, 0-30 ${ }^{\circ} \mathrm{N}$ ), Southern Tropics (ST, 0-30 ${ }^{\circ} \mathrm{S}$ ) and Southern Extra-Tropics (SET, 30-70 $\mathrm{S}$ ).

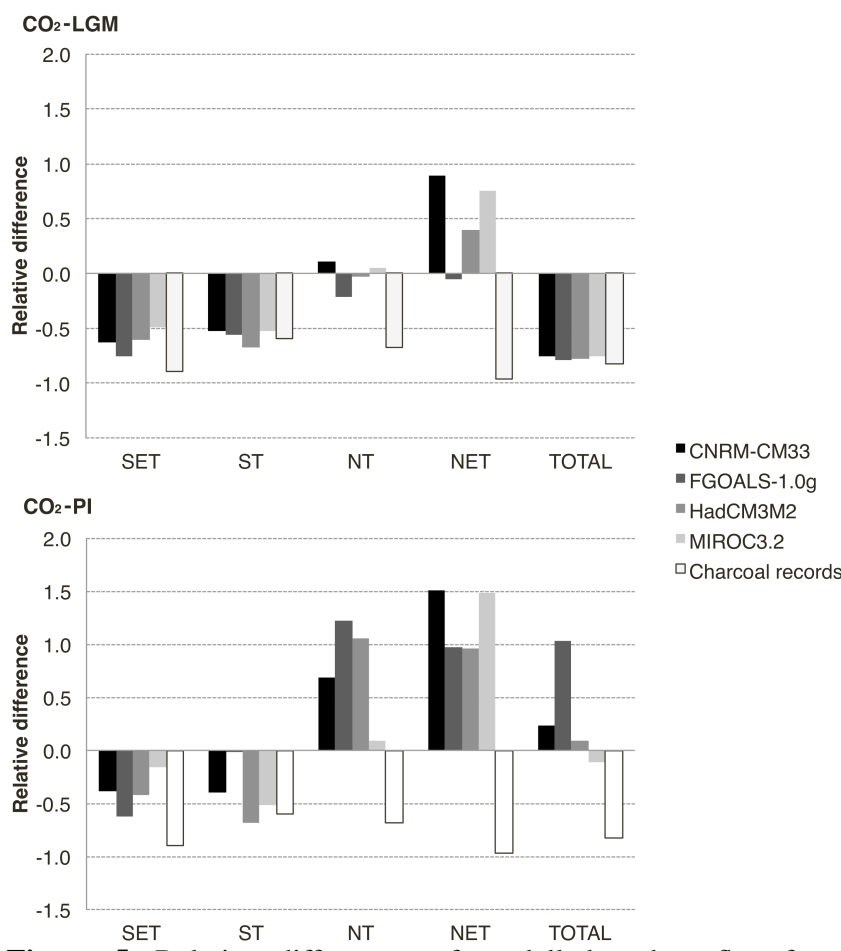

Figure 5. Relative differences of modelled carbon flux from biomass burning by latitude bands, for LGM climate and $\mathrm{CO}_{2}$, and LGM climate with $\mathrm{PI} \mathrm{CO}_{2}$, relative to PI. Observed relative changes in average charcoal index (from data in Daniau et al., 2012) are also shown.

biomass burning flux. Although the modelled area of nonforest burned was greater under LGM conditions, the global amount of $\mathrm{CO}_{2}$ released by fire was considerably less, due to 
Table 2. Percentage of biome area burnt (uncorrected) and biomass burned per unit area and percentage of annual net primary production released into the atmosphere by fire (biome-corrected), for each biome under simulated PI (CRU) and LGM conditions. The LGM climate columns show average results from the four LGM climate scenarios, with $\mathrm{LGM} \mathrm{CO}$ and $\mathrm{PI} \mathrm{CO}_{2}$ respectively. Note that the relative importance of tropical forests is mainly due to the burning fluxes coming from tropical dry forests; the corrections were calculated excluding deforestation fires, which would be relevant today but not for the purposes of this study.

\begin{tabular}{|c|c|c|c|c|c|c|c|c|c|}
\hline & \multicolumn{3}{|c|}{$\begin{array}{l}\text { Annual area burned } \\
\text { relative to total } \\
\text { biome area }(\%)\end{array}$} & \multicolumn{3}{|c|}{$\begin{array}{l}\text { Annual biomass burned } \\
\text { per unit area } \\
\left(\mathrm{g} \mathrm{m}^{-2}\right)\end{array}$} & \multicolumn{3}{|c|}{$\begin{array}{c}\text { Annual biomass burned } \\
\text { relative to NPP } \\
(\%)\end{array}$} \\
\hline & \multirow[t]{2}{*}{ CRU } & \multicolumn{2}{|c|}{ Avg LGM } & \multirow[t]{2}{*}{ CRU } & \multicolumn{2}{|c|}{ Avg LGM } & \multirow[t]{2}{*}{ CRU } & \multicolumn{2}{|c|}{ Avg LGM } \\
\hline & & $\mathrm{CO}_{2}-\mathrm{LGM}$ & $\mathrm{CO}_{2}-\mathrm{PI}$ & & $\mathrm{CO}_{2}-\mathrm{LGM}$ & $\mathrm{CO}_{2}$-PI & & $\mathrm{CO}_{2}-\mathrm{LGM}$ & $\mathrm{CO}_{2}$-PI \\
\hline Tropical forest & 0.39 & 0.001 & 0.20 & 22.55 & 0.82 & 40.16 & 15.74 & 0.10 & 3.71 \\
\hline Warm temperate forest & 0.64 & 0.003 & 0.01 & 0.11 & 0.05 & 0.08 & 0.11 & 0.01 & 0.01 \\
\hline Temperate forest & 0.66 & 0.0 & 0.001 & 0.00 & 0.00 & 0.00 & 0.24 & 0.05 & 0.09 \\
\hline Boreal forest & 0.47 & 0.0 & 0.0 & 5.52 & 6.65 & 13.11 & 0.88 & 1.36 & 2.43 \\
\hline Tropical savannah & 1.51 & 9.23 & 10.30 & 57.70 & 56.30 & 52.76 & 18.91 & 0.04 & 7.01 \\
\hline Sclerophyll woodland & 0.23 & 0.05 & 0.09 & 0.54 & 0.56 & 1.47 & 0.88 & 0.09 & 0.19 \\
\hline Temperate parkland & 1.82 & 6.40 & 8.74 & 1.50 & 1.53 & 2.15 & 1.67 & 0.44 & 0.53 \\
\hline Boreal parkland & 0.41 & 1.60 & 1.98 & 10.22 & 13.11 & 18.67 & 3.61 & 4.28 & 4.98 \\
\hline Dry grass/shrub & 1.93 & 8.22 & 9.56 & 6.23 & 7.80 & 7.88 & 2.51 & 2.62 & 2.58 \\
\hline Desert & 0.74 & 1.75 & 1.61 & 0.06 & 0.34 & 0.21 & 0.74 & 6.98 & 4.55 \\
\hline Shrub tundra & 0.84 & 0.16 & 0.18 & 1.35 & 0.71 & 0.77 & 0.18 & 0.13 & 0.11 \\
\hline Tundra & 0.70 & 0.04 & 0.05 & 0.40 & 0.05 & 0.06 & 0.04 & 0.31 & 0.30 \\
\hline
\end{tabular}

the much lower areal emissions from burning in non-forest biomes.

The model simulations explicitly distinguish the different physiological responses of $\mathrm{C}_{3}$ and $\mathrm{C}_{4}$ plants to $\mathrm{CO}_{2}$ concentration. Tropical savannahs are dominated by $\mathrm{C}_{4}$ grasses, which respond much less strongly to changes in $\mathrm{CO}_{2}$ than $\mathrm{C}_{3}$ plants. The large modelled response of burning in tropical savannahs arises because of their $\mathrm{C}_{3}$ tree component, which makes a major contribution to both the total biomass and the total carbon released from fires in savannahs.

When the simulations are compared with charcoal reconstructions, the simulations with LGM climate and $\mathrm{PI} \mathrm{CO}_{2}$ are shown to produce unrealistic patterns, with very high burning fluxes in the Northern Tropics and Extra-Tropics. Simulations with $\mathrm{LGM}$ climate and $\mathrm{LGM} \mathrm{CO}_{2}$ generate a more plausible latitudinal pattern of changes in biomass burning. There are still differences in the Northern Hemisphere, however. In particular, three of the simulations (driven by outputs from the CNRM-CM33, MIROC 3.2 and HadCM3M2 climate models) showed increases in biomass burning at LGM relative to PI in the Northern Extra-Tropics. There is a simple explanation for this anomaly. The PMIP models generally underestimate the magnitude of observed LGM cooling and drying in the north (Harrison et al., 2014), leading to an unrealistically extensive simulation of forest biomes across much of the hemisphere. Indeed, the relative magnitude of the overestimation in northern biomass burning is consistent with the relative underestimation of the observed cooling by the four climate models: FGOALS-1.0g produces a significant $\left(>8^{\circ} \mathrm{C}\right)$ zonal cooling across northern Siberia, as does HadCM3M2, but MIROC 3.2 and CNRM-CM33 only simulate marked cooling adjacent to the European ice sheet. The PMIP2 climate models used in this study are coupled ocean-atmosphere models with a prescribed land surface, and the LGM vegetation (for climate modelling purposes) was unchanged from the PI control simulations (Braconnot et al., 2007). The presence of forest vegetation as the landsurface condition in the simulations, rather than non-forest vegetation as observed, may provide at least a partial explanation of the simulation of higher-than-observed LGM temperatures across the northern latitudes (Harrison et al., 2014).

The LPX model (Prentice et al., 2011b) has known biases: total biomass burning fluxes are over-estimated in some nonforest biomes, and under-estimated in some forest biomes, most notably the boreal forest (Table 1). There are potentially large uncertainties in the correction factors applied here due to (a) likely direct controls of the bias by climate - the method assumes a correction factor can be applied regardless of climate variations (and possible temporal shifts) within biomes, and (b) the large magnitude of the corrections for some biomes. For example, the application of a correction factor $>300$ for the boreal forest could have contributed to the over-estimation of LGM fires in the Northern ExtraTropics. Another potential source of uncertainty is (c) the assumed similarity between contemporary fire regimes (after removal of those fire emissions assigned by GFED to deforestation, which also involves approximations) and PI regimes. This assumption is, however, consistent with the 
charcoal record, which shows a reduction of biomass burning since peak levels at the beginning of the 20th century - putatively due to land-use shifts - and results in a similar level of biomass burning today and in the PI interval (Marlon et al., 2008). Despite these potential sources of uncertainty, the results presented here demonstrate a very large signal, unambiguously pointing to the involvement of $\mathrm{CO}_{2}$ concentration changes as a major factor in the observed major changes in global fire patterns between glacial and interglacial times.

The fact that fuel loads are directly affected by $\mathrm{CO}_{2}$ changes, irrespective of any changes caused by changing climate, has implications for potential future changes in fire regimes. Many studies have highlighted the possibility of increased fire hazard because of climate warming (e.g. Flannigan et al., 2000); none to our knowledge has previously indicated the possibility that fire risk could increase in areas that do not experience substantial warming because the direct impact of rising $\mathrm{CO}_{2}$ on vegetation productivity could increase fuel loads. Most projections of future fire regimes have been based on statistical modelling approaches (e.g. Krawchuk et al., 2009; Moritz et al., 2012), which by definition cannot account for the independent effects of changes in $\mathrm{CO}_{2}$ on fuel loads because there is negligible (for ecophysiological purposes) large-scale spatial variation in $\mathrm{CO}_{2}$ concentration across the globe. Available model-based assessments (e.g. Scholze et al., 2006; Harrison et al., 2010; Kloster et al., 2010) which in principle do take the ecophysiological $\mathrm{CO}_{2}$ effect into account were made using an older generation of both climate projections and vegetation-fire models. New assessments of future fire risk, using more up-to-date climate scenarios and modelling tools, are urgently needed.

Acknowledgements. Palaeoclimate simulations were from the Palaeoclimate Modelling Intercomparison Project and modern climate data from the Climate Research Unit. We acknowledge the modelling groups participating in PMIP for providing their data for analysis, and the Laboratoire des Sciences du Climat et de l'Environnement (LSCE) for archiving the model outputs. The PMIP2 Data Archive is supported by CEA, CNRS, the EU project MOTIF (EVK2-CT-2002-00153) and the Programme National d'Etude de la Dynamique du Climat (PNEDC). Our analyses were performed using the $12 / 10 / 2006$ version of the database. Pre-industrial data-model comparisons used satellite records from the Global Fire Emissions Database version 3, and palaeodata comparisons were made using raw data from the Global Charcoal Database v2.5, kindly provided by Anne-Laure Daniau, University of Bordeaux. The research leading to these results has received funding from the European Community's Seventh Framework Programme (FP7 2007-2013) under grant agreement no. 238366. Comments by the two anonymous reviewers led to the detection of some errors, and allowed significant improvements in the paper. This paper is a contribution to the AXA Chair Programme in Biosphere and Climate Impacts and the Imperial College initiative on Grand Challenges in Ecosystems and the Environment.
Edited by: A. J. Dolman

\section{References}

Aldersley, A., Murray, S. J., and Cornell, S. E.: Global and regional analysis of climate and human drivers of wildfire, Sci. Total Environ., 409, 3472-81, doi:10.1016/j.scitotenv.2011.05.032, 2011.

Andreae, M. O. and Merlet, P.: Emission of trace gases and aerosols from biomass burning, Global Biogeochem. Cy., 15, 955, doi:10.1029/2000GB001382, 2001.

Bartlein, P. J., Harrison, S. P., Brewer, S., Connor, S., Davis, B. A. S., Gajewski, K., Guiot, J., Harrison-Prentice, T. I., Henderson, A., Peyron, O., Prentice, I. C., Scholze, M., Seppä, H., Shuman, B., Sugita, S., Thompson, R. S., Viau, A. E., Williams, J., and $\mathrm{Wu}, \mathrm{H} .:$ Pollen-based continental climate reconstructions at 6 and $21 \mathrm{ka}$ a global synthesis, Clim. Dynam., 37, 775-802, doi:10.1007/s00382-010-0904-1, 2011.

Batchelder, R. B.: Spatial and temporal patterns of fire in the tropical world, in: Proceedings Annual (6th) Tall Timbers Fire Ecology Conference, edited by: Tall, I., Timbers Research, Tallahassee, FL, 171-207, 1967.

Bennett, J. M., Cunningham, S. C., Connelly, C. A., Clarke, R. H., Thomson, J. R., and Mac Nally, R.: The interaction between a drying climate and land use affects forest structure and above-ground carbon storage, Glob. Ecol. Biogeogr., 1-10, doi:10.1111/geb.12083, 2013.

Bistinas, I., Oom, D., Sa, A., Harrison, S. P., Prentice, C. I., and Pereira, J. M. C.: Relationships between human population density and burned area at continental and global scales, PLoS One, 8, e81188, doi:10.1371/journal.pone.0081188, 2013.

Bistinas, I., Harrison, S. P., Prentice, I. C., and Pereira, J. M. C.: Causal relationships versus emergent patterns in the global controls of fire frequency, Biogeosciences, 11, 5087-5101, doi:10.5194/bg-11-5087-2014, 2014.

Bowman, D. M. J. S., Balch, J. K., Artaxo, P., Bond, W. J., Carlson, J. M., Cochrane, M. A., D’Antonio, C. M., Defries, R. S., Doyle, J. C., Harrison, S. P., Johnston, F. H., Keeley, J. E., Krawchuk, M. A., Kull, C. A., Marston, J. B., Moritz, M. A., Prentice, I. C., Roos, C. I., Scott, A. C., Swetnam, T. W., van der Werf, G. R., and Pyne, S. J.: Fire in the Earth system., Science, 324, 481-484, doi:10.1126/science.1163886, 2009.

Braconnot, P., Otto-Bliesner, B., Harrison, S., Joussaume, S., Peterchmitt, J.-Y., Abe-Ouchi, A., Crucifix, M., Driesschaert, E., Fichefet, Th., Hewitt, C. D., Kageyama, M., Kitoh, A., Laîné, A., Loutre, M.-F., Marti, O., Merkel, U., Ramstein, G., Valdes, P., Weber, S. L., Yu, Y., and Zhao, Y.: Results of PMIP2 coupled simulations of the Mid-Holocene and Last Glacial Maximum - Part 1: experiments and large-scale features, Clim. Past, 3, 261-277, doi:10.5194/cp-3-261-2007, 2007.

Bragg, F. J., Prentice, I. C., Harrison, S. P., Eglinton, G., Foster, P. N., Rommerskirchen, F., and Rullkötter, J.: Stable isotope and modelling evidence for $\mathrm{CO}_{2}$ as a driver of glacial-interglacial vegetation shifts in southern Africa, Biogeosciences, 10, 2001-2010, doi:10.5194/bg-10-2001-2013, 2013.

Ciais, P., Tagliabue, A., Cuntz, M., Bopp, L., Scholze, M., Hoffmann, G., Lourantou, A., Harrison, S. P., Prentice, I. C., Kelley, D. I., Koven, C., and Piao, S. L.: Large inert carbon pool in 
the terrestrial biosphere during the Last Glacial Maximum, Nat. Geosci., 5, 74-79, doi:10.1038/ngeo1324, 2011.

Cowling, S. A.: Plants and temperature- $\mathrm{CO}_{2}$ Uncoupling, Science, 285, 1500-1501, 1999.

Dale, V. H., Joyce, L. A., McNulty, S., and Neilson, R. P.: The interplay between climate change, forests, and disturbances, Sci. Total Environ., 262, 201-204, 2000.

Daniau, A.-L., Harrison, S. P., and Bartlein, P. J.: Fire regimes during the Last Glacial, Quaternary Sci. Rev., 29, 2918-2930, doi:10.1016/j.quascirev.2009.11.008, 2010.

Daniau, A.-L., Bartlein, P. J., Harrison, S. P., Prentice, I. C., Brewer, S., Friedlingstein, P., Harrison-Prentice, T. I., Inoue, J., Izumi, K., Marlon, J. R., Mooney, S., Power, M. J., Stevenson, J., Tinner, W., Andrič, M., Atanassova, J., Behling, H., Black, M., Blarquez, O., Brown, K. J., Carcaillet, C., Colhoun, E. A., Colombaroli, D., Davis, B. A. S., D’Costa, D., Dodson, J., Dupont, L., Eshetu, Z., Gavin, D. G., Genries, A., Haberle, S., Hallett, D. J., Hope, G., Horn, S. P., Kassa, T. G., Katamura, F., Kennedy, L. M., Kershaw, P., Krivonogov, S., Long, C., Magri, D., Marinova, E., McKenzie, G. M., Moreno, P. I., Moss, P., Neumann, F. H., Norström, E., Paitre, C., Rius, D., Roberts, N., Robinson, G. S., Sasaki, N., Scott, L., Takahara, H., Terwilliger, V., Thevenon, F., Turner, R., Valsecchi, V. G., Vannière, B., Walsh, M., Williams, N., and Zhang, Y.: Predictability of biomass burning in response to climate changes, Global Biogeochem. Cy., 26, 1-12, doi:10.1029/2011GB004249, 2012.

Denman, K. L., Brasseur, G., Chidthaisong, A., Ciais, P., Cox, P. M., Dickinson, R. E., Hauglustaine, D., Heinze, C., Holland, E., Jacob, D., Lohmann, U., Ramachandran, S., da Silva Dias, P. L., Wofsy, S. C., and Zhang, X.: Couplings between changes in the climate system and biogeochemistry, in: Climate Change 2007: The Physical Science Basis. Contribution of Working Group I to the Fourth Assessment Report of the Intergovernmental Panel on Climate Change, edited by: Solomon, S., Qin, D., Manning, M., Chen, Z., Marquis, M., Averyt, K. B., Tignor, M., and Miller, H. L., Cambridge University Press, Cambridge, UK and New York, NY, USA, 500-587, 2007.

Farquhar, G. D.: Carbon dioxide and vegetation, Science, 278, 1411, doi:10.1126/science.278.5342.1411, 1997.

Flannigan, M. D., Stocks, B. J., and Wotton, B. M.: Climate change and forest fires, Sci. Total Environ., 262, 221-229, 2000.

Gerten, D., Schaphoff, S., Haberlandt, U., Lucht, W., and Sitch, S.: Terrestrial vegetation and water balance - hydrological evaluation of a dynamic global vegetation model, J. Hydrol., 286, 249-270, doi:10.1016/j.jhydrol.2003.09.029, 2004.

Giglio, L., Randerson, J. T., van der Werf, G. R., Kasibhatla, P. S., Collatz, G. J., Morton, D. C., and DeFries, R. S.: Assessing variability and long-term trends in burned area by merging multiple satellite fire products, Biogeosciences, 7, 1171-1186, doi:10.5194/bg-7-1171-2010, 2010.

Harrison, S. P. and Prentice, C. I.: Climate and CO2 controls on global vegetation distribution at the last glacial maximum: analysis based on palaeovegetation data, biome modelling and palaeoclimate simulations, Glob. Change Biol., 9, 983-1004, doi:10.1046/j.1365-2486.2003.00640.x, 2003.

Harrison, S. P., Marlon, J. R., and Bartlein, P. J.: Fire in the Earth System, in: Changing Climates, Earth Systems and Society, edited by: Dodson, J., Springer Netherlands, 189-199, 2010.
Harrison, S. P., Bartlein, P. J., Brewer, S., Prentice, I. C., Boyd, M., Hessler, I., Holmgren, K., Izumi, K., and Willis, K.: Climate model benchmarking with glacial and mid-Holocene climates, Clim. Dynam., 43, 671-688, doi:10.1007/s00382-013-1922-6, 2014.

Keeley, J. E. and Bond, W. J.: On Incorporating Fire into Our Thinking about Natural Ecosystems: A Response to Saha and Howe, Am. Nat., 158, 664-670, doi:10.1086/323594, 2001.

Kelley, D. I., Prentice, I. C., Harrison, S. P., Wang, H., Simard, M., Fisher, J. B., and Willis, K. O.: A comprehensive benchmarking system for evaluating global vegetation models, Biogeosciences, 10, 3313-3340, doi:10.5194/bg-10-3313-2013, 2013.

Kelley, D. I., Harrison, S. P., and Prentice, I. C.: Improved simulation of fire-vegetation interactions in the Land surface Processes and eXchanges dynamic global vegetation model (LPX-Mv1), Geosci. Model Dev. Discuss., 7, 931-1000, doi:10.5194/gmdd7-931-2014, 2014.

Kloster, S., Mahowald, N. M., Randerson, J. T., Thornton, P. E., Hoffman, F. M., Levis, S., Lawrence, P. J., Feddema, J. J., Oleson, K. W., and Lawrence, D. M.: Fire dynamics during the 20th century simulated by the Community Land Model, Biogeosciences, 7, 1877-1902, doi:10.5194/bg-7-1877-2010, 2010.

Koch, G. W. and Mooney, H. A.: Response of Terrestrial Ecosystems to Elevated $\mathrm{CO}_{2}$ : A Synthesis and Summary, in: Carbon Dioxide and Terrestrial Ecosystems, edited by Koch, G. W. and Mooney, H. A., 443 pp., Academic Press, London, UK, 1996.

Krawchuk, M. A. and Moritz, M. A.: Fire regimes of China: inference from statistical comparison with the United States, Global Ecol. Biogeogr., 18, 626-639, doi:10.1111/j.14668238.2009.00472.x, 2009.

Krawchuk, M. A. and Moritz, M. A.: Constraints on global fire activity vary across a resource gradient, Ecology, 92, 121-32, 2011

Krawchuk, M. A., Moritz, M. A., Parisien, M.-A., Van Dorn, J., and Hayhoe, K.: Global pyrogeography: the current and future distribution of wildfire, PLoS One, 4, e5102, doi:10.1371/journal.pone.0005102, 2009.

Marlon, J. R., Bartlein, P. J., Carcaillet, C., Gavin, D. G., Harrison, S. P., Higuera, P. E., Joos, F., Power, M. J., and Prentice, I. C.: Climate and human influences on global biomass burning over the past two millennia, Nat. Geosci., 1, 697-702, 2008.

Marlon, J. R., Bartlein, P. J., Walsh, M. K., Harrison, S. P., Brown, K. J., Edwards, M. E., Higuera, P. E., Power, M. J., Anderson, R. S., Briles, C., Brunelle, A., Carcaillet, C., Daniels, M., Hu, F. S., Lavoie, M., Long, C., Minckley, T., Richard, P. J. H., Scott, A. C., Shafer, D. S., Tinner, W., Umbanhowar, C. E., and Whitlock, C.: Wildfire responses to abrupt climate change in North America, P. Natl. Acad. Sci. USA, 106, 2519-24, doi:10.1073/pnas.0808212106, 2009.

Middleton, B. A., Sanchez-Rojas, E., Suedmeyer, B., and Michels, A.: Fire in a tropical dry forest of Central America: a natural part of the disturbance regime?, Biotropica, 29, 515-517, 1997.

Mooney, S. D., Harrison, S. P., Bartlein, P. J., Daniau, A.L., Stevenson, J., Brownlie, K. C., Buckman, S., Cupper, M., Luly, J., Black, M., Colhoun, E., D’Costa, D., Dodson, J., Haberle, S., Hope, G. S., Kershaw, P., Kenyon, C., McKenzie, M., and Williams, N.: Late Quaternary fire regimes of Australasia, Quaternary Sci. Rev., 30, 28-46, doi:10.1016/j.quascirev.2010.10.010, 2011. 
Moritz, M. A., Morais, M. E., Summerell, L. A., Carlson, J. M., and Doyle, J.: Wildfires, complexity, and highly optimized tolerance, P. Natl. Acad. Sci. USA, 102, 17912-17917, doi:10.1073/pnas.0508985102, 2005.

Moritz, M. A., Parisien, M.-A., Batllori, E., Krawchuk, M. A., van Dorn, J., Ganz, D. J., and Hayhoe, K.: Climate change and disruptions to global fire activity, Ecosphere, 3, 49, doi:10.1890/ES11-00345.1, 2012.

Moritz, M. A, Hurteau, M. D., Suding, K. N., and D'Antonio, C. M.: Bounded ranges of variation as a framework for future conservation and fire management, Ann. N.Y. Acad. Sci., 1286, 92-107, doi:10.1111/nyas.12104, 2013.

Peltier, W. R.: Global glacial isostasy and the surface of the ice-age earth: The ICE-5G (VM2) Model and GRACE, Annu. Rev. Earth Pl. Sc., 32, 111-149, doi:10.1146/annurev.earth.32.082503.144359, 2004.

Power, M. J., Marlon, J., Ortiz, N., Bartlein, P. J., Harrison, S. P., Mayle, F. E., Ballouche, A., Bradshaw, R. H. W., Carcaillet, C., Cordova, C., Mooney, S., Moreno, P. I., Prentice, I. C., Thonicke, K., Tinner, W., Whitlock, C., Zhang, Y., Zhao, Y., Ali, A. A., Anderson, R. S., Beer, R., Behling, H., Briles, C., Brown, K. J., Brunelle, A., Bush, M., Camill, P., Chu, G. Q., Clark, J., Colombaroli, D., Connor, S., Daniau, A. L., Daniels, M., Dodson, J., Doughty, E., Edwards, M. E., Finsinger, W., Foster, D., Frechette, J., Gaillard, M. J., Gavin, D. G., Gobet, E., Haberle, S., Hallett, D. J., Higuera, P., Hope, G., Horn, S., Inoue, J., Kaltenrieder, P., Kennedy, L., Kong, Z. C., Larsen, C., Long, C. J., Lynch, J., Lynch, E. A., McGlone, M., Meeks, S., Mensing, S., Meyer, G., Minckley, T., Mohr, J., Nelson, D. M., New, J., Newnham, R., Noti, R., Oswald, W., Pierce, J., Richard, P. J. H., Rowe, C., Sanchez-Goñi, M. F., Shuman, B. N., Takahara, H., Toney, J., Turney, C., Urrego-Sanchez, D. H., Umbanhowar, C., Vandergoes, M., Vanniere, B., Vescovi, E., Walsh, M., Wang, X., Williams, N., Wilmshurst, J., and Zhang, H.: Changes in fire regimes since the Last Glacial Maximum: an assessment based on a global synthesis and analysis of charcoal data, Clim. Dynam., 30, 887-907,doi:10.1007/s00382-007-0334-x, 2008.

Power, M. J., Marlon, J. R., Bartlein, P. J., and Harrison, S. P.: Fire history and the Global Charcoal Database: A new tool for hypothesis testing and data exploration, Palaeogeogr. Palaeocl., 291, 52-59, doi:10.1016/j.palaeo.2009.09.014, 2010.

Prentice, I. C. and Harrison, S. P.: Ecosystem effects of $\mathrm{CO}_{2}$ concentration: evidence from past climates, Clim. Past, 5, 297-307, doi:10.5194/cp-5-297-2009, 2009.
Prentice, I. C., Harrison, S. P., and Bartlein, P. J.: Global vegetation and terrestrial carbon cycle changes after the last ice age, New Phytol., 189, 988-98, doi:10.1111/j.1469-8137.2010.03620.x, 2011a.

Prentice, I. C., Kelley, D. I., Foster, P. N., Friedlingstein, P., Harrison, S. P., and Bartlein, P. J.: Modeling fire and the terrestrial carbon balance, Global Biogeochem. Cy., 25, 1-13, doi:10.1029/2010GB003906, 2011b.

Roberts, S. J.: Tropical Fire Ecology, Prog. Phys. Geog., 25, 286-291, 2001.

Rothermel, R. C.: A mathematical model for predicting fire spread in wildland fuels, USDA Forest Service, Ogden, Utah, 1972.

Scholze, M., Knorr, W., Arnell, N. W., and Prentice, I. C.: A climate-change risk analysis for world ecosystems, P. Natl. Acad. Sci. USA, 103, 13116-13120, doi:10.1073/pnas.0601816103, 2006.

Seiler, W. and Crutzen, P. J.: Estimates of gross and net fluxes of carbon between the biosphere and the atmosphere from biomass burning, Climatic Change, 2, 207-247, doi:10.1007/BF00137988, 1980.

Sitch, S., Smith, B., Prentice, I. C., Arneth, A., Bondeau, A., Cramer, W., Kaplan, J. O., Levis, S., Lucht, W., Sykes, M. T., Thonicke, K., and Venevsky, S.: Evaluation of ecosystem dynamics, plant geography and terrestrial carbon cycling in the LPJ dynamic global vegetation model, Glob. Change Biol., 9, 161-185, doi:10.1046/j.1365-2486.2003.00569.x, 2003.

Stott, P.: Combustion in tropical biomass fires:

a critical review, Prog. Phys. Geog., 24, 355-377, doi:10.1177/030913330002400303, 2000.

Stott, P. A., Goldammer, J. G., and Werner, W. L.: The Role of Fire in the Tropical Lowland Deciduous Forests of Asia, in: Fire in the Tropical Biota, edited by: Goldammer, J. G., Ecological Studies, 84, 32-44, doi:10.1007/978-3-642-75395-4_3, 1990.

Thonicke, K., Spessa, A., Prentice, I. C., Harrison, S. P., Dong, L., and Carmona-Moreno, C.: The influence of vegetation, fire spread and fire behaviour on biomass burning and trace gas emissions: results from a process-based model, Biogeosciences, 7, 1991-2011, doi:10.5194/bg-7-1991-2010, 2010. 